УДК 316.74:37(477.64)

DOI https://doi.org/10.32840/2707-9147.2019.84.9

Я. В. ЗОСЬКА

\title{
АНАЛІЗ ПОНЯТТЕВО-КАТЕГОРІАЛЬНОГО АПАРАТУ ДОСЛІДЖЕННЯ СПОЖИВАННЯ ОСВІТНІХ ПОСЛУГ
}

У статті виявлено, щзо споживання є складним комплексом діяльності, який складається з технологї̈ споживання, споживчої діяльності та поведінки споживача.

Доведено, шуо споживання відбувається у свідомості споживача, тобто сторонній спостерігач не може оцінити споживача через етапи иього процесу, окрім зовнішніх проявів. Тому можна стверджувати, що поведінка $\epsilon$ зовнішнім проявом процесу споживання, i саме тому соціологічний аналіз поведінки спожсивачів у вищій школі дозволяє описати не тільки природу діяльності, але і ї̈ зміну під впливом сочіально-економічних факторів та культурних детермінант.

Доведено, щуо інститут освіти бере участь у відтворенні і розвитку соиіальної структури суспільства, у здійсненні сочіальної мобільності й професійного становлення його членів, у структурній перебудові виробництва, у передачі культури, иінностей, традицій і норм поведінки.

Встановлено, щзо використання можливостей декількох методик (LOV ma частково VALS) дозволить розкрити структуру зміни потреб, інтересів і цінностей, стилів життя представників різних соціальних груп і спільнот, виявити їх суспільну природу й домінуючі тенденції транзитивного українського суспільства. Проаналізовано поведінку споживачів послуг вищої освіти, щзо дозволило визначити мотиваційну (потреби, інтереси, ијілі, очікування, установки, запити) й иіннісну (цінності, оцінки, очікування) структуру споживання.

Встановлено, щуо крім задоволення потреби в пізнанні та розумінні, споживання послуг у системі вищої освіти може бути спрямоване на задоволення й інших потреб, таких як належність, любов, визнання, досягнення, репутація, престиж та повага інших, безпека, самоповага та самоактуалізація.

Ключові слова: споживання, освітні послуги, иінності, потреби, стиль життя, поведінка.

Вища освіта на сучасному етапі розвитку українського суспільства набула особливого значення, іiі визначна роль полягає у формуванні соціальної структури суспільства, соціалізації й професійному спрямуванні молоді, відтворенні, збереженні та розвитку інтелекту нації. Зміст і стан вищої освіти, іiї соціального інституту залежить від соціально-політичної, соціально-економічної, соціокультурної детермінації.

Для емпіричного дослідження умов формування ринку послуг вищої освіти, на нашу думку, доцільно було б розробити аналітичний інструментарій, що потребує пильного аналізу досліджуваних понять

(C) Зоська Я. В., 2019 
[11, с. 112]. Оскільки поведінку споживачів різних товарів і послуг, насамперед освітніх, ми розглядаємо в логічному взаємозв'язку 3 поняттями «поведінка» і «споживання», для аналізу їх співвідношення з'ясуємо суть кількох підходів щодо їх визначення.

Метою статті є аналіз поняттєво-категоріального апарату дослідження споживання освітніх послуг.

Освіта як соціальний інститут і соціальні аспекти вищої освіти постійно привертали увагу соціологічної професійної спільноти (В. Астахова, І. Гавриленко, В. Городяненко, О. Скідін, П. Куделя, В. Луговий, М. Лукашевич, М. Руткевич, Б. Рубін, В. Шубкін). У вітчизняній соціології було сформовано базис досліджень, присвячених аналізу різноманітних поведінкових рис молоді й студентства (Л. Аза, В. Арбєніна, В. Бакіров, Є. Головаха, С. Макєєв, Б. Нагорний, В. Ніколаєвський, Н. Побєда, Л. Сокурянська, С. Оксамитна, О. Якуба). Поведінка із задоволення потреб в освіті починається з порушення стану рівноваги. Почуття невдоволення своїм становищем у суспільстві чи занепокоєння щодо стабільного майбутнього порушує рівновагу людини. Для відновлення свого стану вона прагне здійснити ряд дій, спрямованих на зміцнення статусної позиції в соціальному просторі завдяки нарощуванню людського капіталу. Підвищення освітнього рівня сприяє накопиченню людського капіталу і визначенню соціальної позиції. Оскільки досягнення сприятливого стану стає можливим за наявності високого освітнього рівня, в українському суспільстві відзначено підвищений попит на послуги вищих навчальних закладів.

Під поведінкою П. Сорокін розумів сукупність вчинків, які, незважаючи на всю свою різнорідність, безпосередньо пов'язані зі здійснюваними діями $[19$, с. 53-60]. Тому можна відзначити, що поведінка споживачів, насамперед освітніх послуг, спрямована на досягнення мети.

Суттєве значення для нашого дослідження має структура поведінки, представлена В. Ядовим. Вона включає такі елементи, як поведінковий акт і вчинок (звична дія). Поведінковий акт розглядається вченим як специфічна реакція суб'єкта на актуальну предметну ситуацію, відгук на специфічні впливи зовнішнього середовища. Вчинок (звична дія), на думку В. Ядова, складається 3 поведінкових актів і є елементарною соціально-значимою одиницею поведінки. Мета вчинку - встановлення відповідності між найпростішою соціальною ситуацією та соціальною потребою (чи потребами) суб'єкта [22, с. 92-98]. Умовно за одиницю поведінки можна прийняти соціальний акт, вчинок, дію в процесі споживання освітніх послуг.

Споживання, згідно з визначенням В. Тарасенка, це багатофункціональна діяльність, у процесі якої відбувається задоволення потреб людей i доцільне використання речей і предметів [21, с. 10-11]. Споживання є складним комплексом діяльності, що складається 3 технології споживання, споживчої діяльності та поведінки споживача. 
О. Донченко відзначає, що мотиви, інтереси і потреби зумовлюють активність споживачів. Споживання розуміється як форма соціальної діяльності, що інтегрує в собі спонукальний, виконавчий і поведінковий моменти активності особистості. У структуру споживання включені: потреби як його вихідний компонент-спонукач; предмети споживання; поведінка $[10$, с. 14,25$]$. Поведінка розглядається як спосіб здійснення діяльності зі споживання.

Споживання відбувається у свідомості споживача, тобто сторонній спостерігач не може оцінювати проходження споживачем стадій цього процесу інакше, як за зовнішніми проявами. Отже, поведінка $є$ зовнішнім проявом процесу споживання, тому соціологічний аналіз поведінки споживачів послуг у системі вищої освіти дозволяє описати не тільки характер діяльності, але і їі зміну під впливом соціально-економічних факторів і культурних детермінант.

В. Тарасенко узагальнює і систематизує дослідницькі варіанти аналізу споживання в межах соціологічного підходу і виділяє такі: діяльнісний, системний, ціннісний, інституціональний, структурно-функціональний і стратифікаційний [21, с. 23].

Аналіз споживання освітніх послуг не можливий без виділення його елементів (структур), визначення їх місця і ролі (функцій) у цілісній взаємодії. Для цього необхідно застосувати структурно-функціональний підхід. У сучасній соціології в структурі споживання визначають наявність таких структур: мотиваційної (потреби, інтереси, цілі, очікування, настанови, запити); ціннісної (споживчі цінності, оцінки, споживчі очікування); діяльнісної; поведінкової (форми споживчої поведінки); матеріально-організаційної (підприємства сервісу, домашнє господарство; самодіяльні організації споживачів).

Однак вивчення лише структури споживання не дозволить розкрити багаторівневий характер і його цілісність. Це можливо завдяки діяльнісному підходу, оскільки особисте споживання представляє процес соціальної діяльності в єдності їі загальних елементів: мета, засіб, результат.

Вивчаючи споживання освітніх послуг як процес соціальної діяльності, обов'язково виникає необхідність у розумінні суті ідеології процесу споживання, що виражає його ціннісний зміст і вироблений їм соціальний ефект. Саме ціннісний підхід спрямовано на дослідження ролі споживчих цінностей у мотиваційній системі поведінки споживачів, аналіз соціальної значущості і спрямованості споживання [17].

Вивчаючи тільки ідеологію особистого споживання, не можна виявити складну багатопланову структуру споживання у взаємодії різних груп споживачів. Саме тому для визначення причин прояву i реалізації різних ліній поведінки певних груп споживачів буде сприяти стратифікаційний підхід. Однак він не надає можливості розглядати споживання освітніх послуг як окремий соціальний інститут у єдності діяльності і відносин. Лише в межах інституціонального підходу 
можливий розгляд споживання у вигляді особливого структурного компонента інституту освіти, соціальної діяльності й соціальної організації суспільства.

Важливе значення має системний підхід, що надає можливість проведення аналізу процесу споживання освітніх послуг як певного самостійного і цілісного компонента процесу освіти.

Споживання послуг вищої освіти в межах діяльнісного підходу виступає особливою формою соціальної діяльності, котра здійснюється різними способами i, відповідно, має різні типи поведінки споживачів. Предметом підходу є закономірності процесу споживання, a предметним полем нашого дослідження виступають принципи i технології, що визначають формування поведінки споживачів послуг у системі вищої освіти.

Згідно з Ф. Котлером, «поведінка споживача»-це процес прийняття рішень, під час якого визначається потреба в товарах або послугах, виявляються, оцінюються і вибираються конкретні постачальники чи марки товару з числа альтернативних [14, с. 179-189].

Наявність потреби - це передумова будь-якої діяльності, проте власне потреба не може додати діяльності визначеної спрямованості [21]. Тому аналіз потреб неминуче буде стикатися 3 аналізом мотивів, оскільки мотиви несуть у собі дійсну і змістовну характеристику потреб.

У наш час вивченню мотивів присвячено величезну кількість робіт, в яких мотиви визначають по-різному: апетит, потяги, імпульси, звички, навички, бажання, емоції тощо. Поведінка споживачів послуг у системі вищої освіти мотивована. В основу структури їх діяльності покладено ті ж мотиви, що й в основу інших соціальних дій: цілі, звички, традиції родини і найближчого оточення, цінності й інтереси суспільства (соціальних груп), афекти, імпульси, бажання, емоції, честолюбство, ідеали.

Мотивація в людини починається 3 появи стимулу, котрий може мати внутрішню (результат фізіологічних змін) і зовнішню природу (результат спостереження, сприйняття предметів споживання). Якщо стимул викликає розбіжність реального і бажаного стану людини, то відбувається усвідомлення потреби як їі вихідного компонента-мети споживання.

У численних інтерпретаціях потребу визначають як властивість усього живого, що виражає первісну, вихідну форму активного, вибіркового ставлення до умов зовнішнього середовища. Формування потреб відбувається під впливом культури суспільства в результаті розвитку сфер життєдіяльності.

Розрізняють первинні і вторинні, біологічні і соціальні потреби. Залежно від сфери діяльності людини існують потреби праці, пізнання, спілкування, відпочинку тощо; залежно від об'єкта споживання - потреби матеріальні і духовні, етичні й естетичні. За суб'єктом 
споживання визначають індивідуальні, групові, колективні, суспільні потреби [20, с. 254]. За ступенем раціональності споживання розрізняють розумні (раціональні) і ірраціональні потреби [8, с. 26].

A. Маслоу запропонував розглядати потреби особистості у вигляді iєpapxiï:

- фізіологічні базові потреби (позиви): голод, спрага, сексуальний потяг;

- потреба в безпеці і стабільності, залежності, захисті, потреба в структурі, порядку, законі, обмеженнях;

- потреба в приналежності і любові, родині, друзях;

- потреба у визнанні: потреби «досягнення» (відчуття власної значущості, компетентності, почуття волі, незалежності, упевненості); потреби в репутації і престижі, у завоюванні статусу, уваги, визнання, слави;

- потреба в самоактуалізації, самовтіленні, самореалізації.

Угорі знаходяться найбільш складні потреби в пізнанні й розумінні, естетичні потреби. В основі людських прагнень до знань лежать не тільки негативні детермінанти (тривога і страх), що виводять людину зі стану рівноваги, але і позитивні імпульси - інтерес, потреба в тлумаченні та розумінні. Говорячи про потреби в пізнанні, варто констатувати, що дуже часто їх не відрізняють від процесу навчання.

Задоволення власних потреб пов'язане з одержанням задоволення - в основу може бути покладений принцип граничної корисності чи одержання почуттєвої насолоди. На цій підставі виділяють утилітарні й гедоністичні потреби. Утилітарні пов'язані з об'єктивними характеристиками об'єкта споживання, його функціональним призначенням. Гедоністичні - iз суб'єктивним сприйняттям товару (послуги), емоційними очікуваннями від споживання, а також $з$ етичними аспектами. Насамперед вони пов'язані з задоволенням потреби в насолоді, задоволенні, зручності [1, с. 310]. Споживання послуг у системі вищої освіти пов'язано і з функціональним, і з почуттєвим очікуванням від задоволення потреби, тому вони мають як утилітарний, так і гедоністичний характер одночасно.

Потреби виникають і розвиваються в процесі життєдіяльності людини, демонструють прагнення людини до досягнення об'єктивно необхідних умов життя, що забезпечують певний добробут і всебічний розвиток особистості. Особливістю системи власних потреб є те, що всі вони не взаємозамінні. Так, задоволення потреби у вищій освіті (особливо на платній основі), не може виключити задоволення фізіологічних потреб, потреб у безпеці. А повне задоволення потреби в їжі не замінить необхідності задоволення потреби в житлі, одязі чи духовних потребах. Взаємозамінність може мати місце тільки по відношенню до конкретних предметів, що задовольняють окремі види потреб.

Необхідністю в розумінні потреб є визначення таких груп: фізичні, соціальні, духовні й інтелектуальні. Соціальні потреби виникають 
у зв'язку з життєдіяльністю людини в суспільстві, формуються в процесі становлення людини як особистості, їі розвитку як члена суспільства. До цієї групи можна віднести потреби в суспільній діяльності, самовираженні, спілкуванні з людьми, забезпеченні соціальних прав та інші.

Інтелектуальні потреби пов'язані з інтелектуальною діяльністю, розвитком i підвищенням інтелектуального рівня, формуються в процесі становлення людини як особистості. До інтелектуальних потреб відносять: потреби в пізнанні навколишнього світу, освіті, підвищенні кваліфікації, різних видах творчої діяльності.

Залежно від рівня конкретизації всі потреби поділяються на загальні і конкретні. Кожна загальна потреба, що визначається видом діяльності, може бути представлена кількома конкретними, зумовленими предметами споживання. 3 іншого боку, набір окремих конкретних потреб може скласти одну загальну. Наприклад, якщо розглядати споживання послуг у системі вищої освіти, то загальною потребою виступає здобуття освіти відповідного рівня. Конкретними потребами можуть виступати: здобуття вищої освіти у визначеному ВНЗ, за певною спеціальністю та 3 відповідним рівнем кваліфікації: «бакалавр», «магістр».

Частина потреб залишається незадоволеною через недостатній рівень розвитку економічної сфери суспільства, нестачу окремих предметів споживання, низький рівень прибутків споживачів. Так, потреба в здобутті вищої освіти може залишитися незадоволеною, оскільки вона без підкріплення споживача матеріальними ресурсами не оформиться як платоспроможна i, відповідно, залишиться незадоволеною (для платної освіти). Відповідно до соціально-економічного розвитку суспільства все більша частина незадоволених потреб задовольняється, але водночас з'являються нові незадоволені потреби.

Задоволення потреби в здобутті вищої освіти може розглядатися як нераціональна дія, якщо не задоволені основні фізіологічні потреби людини. Доцільність і раціональність одержання вищої освіти може бути поставлена під сумнів й у зв'язку з падінням віддачі від освіти, зумовленої кількома причинами. Потребу в здобутті освіти все частіше пов'язують не з придбанням «валізи знань», а з одержанням кваліфікації і відповідного диплома з урахуванням умов ринку праці й розвитку в ньому сектора дипломованих фахівців [9, с. 175-176, 337]. 3 погляду економічної доцільності інвестицій у одержання платної освіти ефект може бути мінімальним, оскільки різниця між заробітком високоосвіченої і неосвіченої людини може бути зведена до розходження в діяльності активної й пасивної людини. Поряд 3 цим здобуття вищої освіти (якщо не задоволені фізіологічні потреби) може розглядатися водночас і як раціональна дія, бо вона, по-перше, схвалена інформаційним суспільством; по-друге, дозволить збільшити культурний капітал; по-третє, може сприяти соціальній мобільності; по-четверте, відкриває можливості отримати в майбутньому зиск (спеціальність, посаду, соціальний статус, престиж). 
Потреби більшістю людей не усвідомлюються або усвідомлюються частково. В основі поведінки - множинна мотивація, тобто жодна з базових потреб не стає єдиною. Так, поведінка споживачів послуг у системі вищої освіти спрямована не тільки на задоволення когнітивних потреб і не тільки допомагає адаптації людини в суспільстві, але й дозволяє задовольнити деякі базові потреби.

Так, споживання послуг у системі вищої освіти, окрім задоволення потреби в пізнанні й розумінні, може бути спрямоване на задоволення декількох потреб:

- у приналежності і любові - допомагають мати теплі, дружні відносини в групі високоосвічених людей, з високим статусом;

- у визнанні, що має такі вирази: у досягненні - формують почуття власної значущості, компетентності, незалежності і свободи в інформаційному суспільстві; у репутації, престижі й повазі оточуючих дозволяють завойовувати статус, повагу, визнання [16, с. 340-341] та породжують почуття впевненості в собі;

- у безпеці - надають можливість зайняти своє місце в соціальній структурі суспільства, забезпечити себе роботою і заробітком, сталістю й упорядкуванням повсякденного життя, запобігти страху та занепокоєнню;

- у самоповазі й самоактуалізації - допомагають реалізувати прагнення до актуалізації закладених здібностей i їх вираження; презентують стиль життя, соціальне положення, матеріальний стан.

Формування потреб людини відбувається під впливом соціуму. Усі потреби людини, як вищі, так і нижчі, мають суспільну природу, оскільки ії діяльність, опосередкована суспільними умовами життя, і об'єкти діяльності, з'являються в процесі суспільної праці. Т. Парсонс відзначав, що людина як соціальний діяч у процесі життєдіяльності вступає у взаємодію із середовищем, яке має системний характер. Соціальна система також має визначені потреби, задоволення яких необхідно як з погляду відносин між соціальною системою і її середовищем, так і 3 погляду внутрішнього функціонування системи. T. Парсонс визначив чотири функціональних потреби (відомих як AGIL): адаптація - потреба співвіднесення з навколишнім середовищем під час використання ії ресурсів; ціледосягнення - формулювання завдань, окреслених перед системою; інтеграція - підтримка внутрішнього порядку; підтримка латентного зразку - вироблення мотивації для виконання завдань [16]. Для задоволення кожної з цих функціональних потреб складаються групи й підсистеми дій. Таким чином, соціальна взаємодія має багаторівневу структуру, де кожен елемент і підсистема для свого виживання задовольняє ці чотири функціональні потреби.

Для розуміння поведінки споживачів, у тому числі й послуг вищої освіти, важливе знання систем соціальної взаємодії та особливостей ïx функціонування. Споживаючи освітні послуги, людина як представник суспільства (певної його групи) окреслює перед собою мету - 
одержати визначений рівень освіти та координує їі згідно із загальною метою соціальної спільноти. При цьому людина піклується про свою адаптацію в соціальному просторі й інтеграцію у визначенні такої соціальні страти, як середній клас. Достатньою мотивацією для споживача освітніх послуг можуть виступати потреби, інтереси, цінності і культура суспільства, соціальних груп.

Соціальна взаємодія людини в процесі споживання освітніх послуг ілюструє суспільну природу їі потреб і тісний взаємозв'язок iï поведінки із суспільними умовами життя. Так, задоволення потреби в здобутті освіти членами суспільства певним чином пов'язане із задоволенням потреби суспільства в стабільності. Соціальний інститут освіти, що реалізує основні функції, сприяє стабільності суспільства, його соціальному розвиткові завдяки оформленню організаційної структури і впливає на всі сфери життя суспільства. Роль освіти полягає не тільки в розширенні знань про життєві умови, соціалізацію членів суспільства, але й у наданні необмежених можливостей у пізнанні [15, с. 14]. Мета освіти може розглядатися як «оснащення» членів суспільства навичками самостійного існування в реальному світі - здібностями заробляти гроші (з позицій економістів). Отже, інститут освіти бере участь у відтворенні і розвитку соціальної структури суспільства, у здійсненні соціальної мобільності й професійного становлення його членів, у структурній перебудові виробництва, у передачі культури, цінностей, традицій і норм поведінки.

Особливу роль у задоволенні потреб суспільства виконує система вищої освіти. Система освіти в університетах задовольняє кілька потреб суспільства одночасно: продукування професіоналів; соціалізація його членів (забезпечує засвоєння ними цінностей, норм своєї соціальної групи); виробництво й передачу професійного знання; регулювання ринків професійних послуг через видачу дипломів і сертифікатів; легітимацію професійного знання [4, с. 34-46].

Інтереси передусім спрямовані на соціальні об'єкти: для одних це «законні домагання» на сформований рівень споживання, для інших прагнення до якісної зміни умов життя. Виходить, що в інтересах відображається соціальний стан індивідів, що й зумовлює їх роль як найважливіших зовнішніх спонукальних стимулів дії. Оскільки єдність інтересів спільноти визначається насамперед соціально-економічним становищем тих, хто входить до ії складу, ми можемо скласти уявлення про структуру інтересів різних соціальних груп.

Інтерес суспільства в освіті його членів має і економічну, і соціальну природу. Економічний інтерес виявляється в забезпеченні загального добробуту членів суспільства, що можливо в соціально розвиненому суспільстві з високою організаційною структурою. Для формування і регулювання соціальної структури необхідно професійне становлення молоді, а також рівний доступ до освіти [13] 3 метою вертикальної мобільності сходами соціальної ієрархії. Під час 
перебігу процесу ускладнення структури суспільства варто забезпечити безперервну освіту, перепідготовку й підвищення кваліфікації його членів. Тому соціальний інтерес постіндустріального суспільства полягає в становленні і розвитку його структури, у розгляді освіти як соціокультурного фактору. У процесі соціалізації культура і її символи засвоюються зростаючим поколінням. У процесі морального і правового виховання освоюються соціальні норми. Освіта формує амбіції і прагнення зайняти високу позицію чи статус.

Отже, ідеологічні, соціально-економічні і духовні інтереси членів суспільства формуються під впливом сім’ї, соціальних груп, системи виховання, освіти, релігії, ідеології. Інтереси споживача своєю чергою це безпосереднє відображення стилю життя певної спільноти, в якому відбито результат взаємного впливу економічних, соціальних та культурних чинників. Життєвий стиль відображає не тільки єдність інтересів, але й схожість думок, типові форми поведінки та діяльності представників означеної групи. Тому аналіз формування ринків повинен стикатися $з$ дослідженням стилів життя споживачів й фокусувати увагу на діяльності, інтересах та думках.

Єдність інтересів і подібність думок, практики споживання i, як наслідок, стилю життя знаходиться не тільки під впливом соціальних груп, але й багато в чому залежить від культури, цінностей [12]. Так, вища освіта має велике значення не тільки для представників середнього класу, але й для тих, хто намагається співвіднести себе 3 цим класом і розглядає цінність здобуття вищої освіти як забезпечення вертикальної соціальної мобільності (наближення до середнього класу).

Цінність в одержанні вищої освіти для більшості українців може розглядатися з погляду реалізації їх інтересів у збільшенні культурного капіталу, досягненні визначеного статусу, престижу й становища в суспільстві, покращення добробуту.

Ставлення особистості до цінностей покладено в основу поняття «ціннісні орієнтації». Згідно $з$ типовим визначенням - це «соціальні цінності, які особистість розподіляе і які виступають цілями дій та основних засобів їх досягнення, вони є найважливішим фактором, що регулює та детермінує мотивацію особистості» [20, с. 403].

Цінності можуть бути персональними й соціальними. Соціальні цінності - ті, що визнає група, детермінують «нормальну» поведінку в суспільстві. Соціальні цінності впливають на формування персональних цінностей, які своєю чергою визначають «нормальну» поведінку для індивідуума [3, с. 705; 6, с. 232]. Персональні цінності споживача по відношенню до досягнень і задоволень можуть, наприклад, визначати, у якій пропорції він поділяє свій час між професійним розвитком і розвагами. Таким чином, персональні цінності відображають вибір ціннісних орієнтацій людини з існуючих ціннісних систем. У своїй практичній діяльності людина, зіштовхуючись 3 необхідністю 
оцінювання, використовує умовну шкалу цінностей, яка існує у іi свідомості як класифікатор (ментальна структура). Цінності завжди можна впорядкувати за допомогою сформованої умовної шкали, що має протилежні полюси. За допомогою цієї шкали людина структурує навколишній світ, розкладає предмети і явища за критерієм їх цінності (корисності). У результаті відбувається конструювання соціальної реальності за допомогою цієї ментальної структури - шкали цінностей. Використання знання про персональні цінності в дослідженнях поведінки споживачів уможливлює проведення аналізу структури населення за гомогенними групами та визначити їх відношення до загальних систем цінностей.

Цінності виступають важливими регуляторами поведінки людей у всіх сферах, у тому числі й у споживанні послуг вищої освіти. Соціологи і маркетологи в практиці проведення досліджень споживачів застосовують методику оцінки впливу цінностей Д. Хокінса, Р. Беста і К. Коні, які виділяють такі типи цінностей, як орієнтовані на інших, на середовище, на себе [2]. Така методика дозволяє виявити спрямованість поведінки споживачів послуг у системі освіти, їі залежність від суспільного визнання та оцінки.

Поряд 3 цим активно використовується методика опису цінностей (LOV), що створена вченими Мічиганського університету на теоретичній базі А. Маслоу та М. Рокіча. Ї̈̈ активно застосовують для опису впливу таких цінностей, як: 1) самоповага; 2) безпека; 3) теплі відносини $з$ людьми; 4) відчуття завершеності; 5) самореалізація; 6) відчуття приналежності; 7) повага з боку оточення; 8) розвага та задоволення в житті; 9) натхнення. За цією методикою споживачів можна диференціювати за двома категоріями відповідно до спрямованості їх дій на внутрішній (номери 1, 3, 4, 5, 8, 9 переліку цінностей) або зовнішній фокус (номери $6,7,2$ ). Визначені цінності можуть бути втіленні в життя через міжособові стосунки (номери 6, 3), особистісні фактори (номери $1,5,7)$ чи завдяки особистим речам (номери $2,4,8,9)$.

Зміна соціальної практики веде до зміни цінностей, тому що вони мають конкретно-історичний характер. Окрім того, у межах одного суспільства, того ж самого часу є різні субкультури, які можуть мати piзні, а то й протилежні цінності. Дослідження їх змісту є важливим для розуміння трансформації суспільства, його сфер діяльності, а також для розкриття механізмів регуляції поведінки споживачів.

Цінності пов'язані як з формуванням цілей, так і з вибором шляхів їх досягнення - саме це відзначив у своїй методиці дослідження М. Рокич, розділивши цінності на термінальні, пов'язані з кінцевими станами, до яких прагне людина, та інструментальні, що характеризують шляхи досягнення кінцевих станів [5]. Таке дослідження наближує до розуміння загальноприйнятих цінностей, сенсу життя та прийнятних зразків поведінки, але формування гомогенних груп та обгрунтування їх дій на підставі цієї методики досить ускладнено. 
Аналіз соціальної поведінки, що визначається потребами, інтересами, демонструє певний стиль життя та водночас узгоджується 3 цінностями, дозволяє зробити сучасна методика - VALS, VALS2 [1]. Вона описує зв'язок цінностей і стилів життя й дозволяє провести аналіз рівня задоволення потреб за пірамідою А. Маслоу (це може надати інформацію про сукупний обсяг капіталу особистості) та орієнтованості дій споживачів (іх рівень залежності від оточення).

Соціальна поведінка визначається потребами і пов'язана $з$ інтересами, цінностями та множиною зовнішніх соціальних факторів. Так, В. Ядов відзначав роль соціокультурних детермінант у регулюванні соціальної поведінки і приділяв особливу увагу настановам (диспозиціям). Настанова - це схильність до дії як деякий стан психіки індивіда. Важливість іiі розгляду визначається тим, що існує залежність настанов від соціокультурного середовища i нерозривний зв'язок між ними [18]. Дослідник виділяв чотири рівні регуляції соціальної поведінки особистості. Нижчий рівень - це настанови, що регулюють найпростіші реакції суб'єкта на актуальну предметну ситуацію. Другий рівень утворюють соціальні настанови - особистість виробляє визначене ставлення до соціальних об'єктів на основі трьох компонентів: емоційного, когнітивного й поведінкового. Третій рівень - базові соціальні настанови, які характеризують загальну спрямованість інтересів особистості на область діяльності і формуються на основі складних соціальних потреб. Четвертий рівень утворює система ціннісних орієнтацій, пов'язаних 3 вищими цілями життєдіяльності індивіда, його потребами.

Таким чином, ми відзначаємо, що ціннісні орієнтації регулюють цілісність поведінки, усю діяльність людини в найбільш значимих ситуаціях їі соціальної активності. Варто погодитися 3 думкою В. Бакірова про велике значення цінностей для аналізу поведінки споживачів, оскільки цінність як регулятор соціальної поведінки виникає лише тоді, коли предмет реально цікавить людину, визначає цілі їі діяльності, підштовхує до визначених дій [7]. До того ж цінності виявляють свою значущість уже на стадії усвідомлення потреби, а також використовуються на стадії формування споживачем критеріїв оцінки.

Таким чином, поведінка споживача $є$ зовнішнім проявом діяльності по споживанню і розглядається лише як спосіб здійснення. Необхідною передумовою будь-якої діяльності $є$ наявність потреби як внутрішнього стимулу. В основу діяльності покладено систему потреб, пов'язану із взаємодією функціональних структур складного організму людини. Формування потреб відбувається під впливом культури суспільства й у результаті розвитку різних сфер життєдіяльності. Отже, потреби мають суспільну природу.

Мотивація представляється як процес вибору між різними діями, процес, що регулює і спрямовує дію на досягнення специфічних 
цільових станів, що підтримує цю спрямованість і визначення предметів діяльності, які задовольняють потребу людини. Мотиви невидимі, вони формуються в процесі індивідуального розвитку як відносно стійкі оцінні установки.

Висновки. Цінності як елемент культури займають особливе місце у формуванні поведінки - виступають регулятором поведінки, обмежують або розширюють можливість набору потреб людини як істоти соціальної, надають значення і зміст предметам споживання. За допомогою шкали цінностей людина структурує навколишній світ за принципом корисності предметів і явищ.

Дослідження й аналіз поведінки споживачів дозволить розкрити динамічну структуру зміни потреб, інтересів і цінностей представників різних соціальних груп і спільнот, виявити суспільну природу i домінуючі тенденції. Методичний базис для проведення дослідження має велику кількість різновидів, що вимагає від дослідників критичного ставлення до них та адекватної селекції згідно з окресленим колом завдань, спонукає до поєднання декількох запропонованих методик, зокрема LOV та частково VALS, та вимагає від дослідника комплексного їх використання.

Становлення ринкових відносин, стабілізація економічної та соціальної сфер суспільства, призвели до трансформації структури суспільства i, як наслідок, до еволюції поведінки споживачів. Таким чином, активно формується високий попит на вищу освіту. Це сприяє більш активному впливу освіти на соціальну структуру суспільства, зокрема інтенсифікує соціальну мобільність населення.

\section{Список використаної літератури}

1. Endgel J.F., Blackwell R.D., Miniard P. W Consumer Behavior. 8-th ed. The Dryzen Press, $1995.951 \mathrm{p}$.

2. Hawkins D.I., Best R.J., Coney K.A. Consumer Behavior: Implications for Marketing Strategy. 5-th ed. IRWIN, 1995. 649 p.

3. Mowen J.C. Consumer Behavior. 4-th ed. Macmillan Publishing Co., 1995. 862 p.

4. Parsons T. The Professions and Social Structure (1939) // Parsons T. Essays in Sociological Theory (Revised Edition). New-York The Free Press, 1966. P. 34-46.

5. Rokeach M. The open and clozed mind. New York : Basik Books. 1973.

6. Алешина Н.В. Поведение потребителей: Учеб. пособие для вузов. Москва : ФАИР-ПРЕСС, 1999. 384 с.

7. Бакиров В.С. Ценностное сознание и активизация человеческого фактора. Харьков : Вища шк., 1988. 147 с.

8. Баранова Л.Я., Левин А. И. Потребности, доходы, потребление : Экон. словарь-справочник. Москва : Экономика, 1988. 351 с.

9. Большой толковый социологический словарь (Collins) / Сост. Д. Джери., Д. Джери. ; Пер. с англ. Н.Н. Марчук. Москва : Вече, АСТ, 2001. Т. 2 (П-Я). 528 с.

10. Донченко Е.А. Потребление и развитие личности (социально-психологический анализ). Київ : Наук. думка, 1982. 255 с. 
11. Зоська Я.В. Анализ методики социо-психографического подхода исследования потребителей. Социальныле технологии. Киев : ГУ «ЗИГМУ», 2004. Вип. 23. С. $110-118$.

12. Жилина Л.Н. Потребности, культура потребления и ценностные ориентации. Москва : Мысль, 1988. 220 с.

13. Конституція України. Київ : Укр. центр правничих студій, 2006. 126 с.

14. Котлер Ф. Основы маркетинга / Пер. с англ. В.Б. Боброва. Москва, 1996. $704 \mathrm{c}$.

15. Лукашевич М.П. Соціологія економіки. Київ : Каравела, 2005. 288 с.

16. Парсонс Т. Система современных обществ / Пер. с англ. Л.А. Седова, А.Д. Ковалева. Москва : Аспект Пресс, 1998. 271 с.

17. Ручка А.А. Ценностный подход в системе социологического знания. Київ : Наук. думка, 1987. 156 с.

18. Самоорегуляция и прогнозирование социального поведения личности / Под ред. В. А. Ядова. Ленинград : Наука. Ленигр. отд-ние, 1979. 264 с.

19. Сорокин П.А. Человек. Цивилизация. Общество. Москва : Политиздат, 1992. $543 \mathrm{c}$.

20. Социологический энциклопедический словарь. На русском, английском, немецком, французском и чешском языках / Ред. Г.В. Осипов. Москва : ИНФРА-МHOPMA, 1998. 488 c.

21. Тарасенко В.И. Социология потребления: Методологические проблемы. Киев : Наук. думка, 1993. 168 с.

22. Ядов В.А. О диспозиционной регуляции социального поведения личности. Методологические проблемы сочиальной психологии. Москва, 1975. С. 92-98.

\section{Зоська Я. В. Анализ понятийно-категориального аппарата исследования потребления образовательных услуг \\ $B$ статье выявлено, что потребление является сложным комплексом} деятельности, который состоит из технологии потребления, потребительской деятельности и поведения потребителя.

Доказано, что потребление происходит в сознании потребителя, то есть сторонний наблюдатель не может оценить потребителя на других этапах этого процесса, кроме как с помощью внешних проявлений. Таким образом, можно утверждать, что поведение является внешним проявлением процесса потребления, и поэтому сочиологический анализ поведения потребителей в выстем образовании позволяет нам описьвать не только характер деятельности, но и ее изменение под влиянием социально-экономических факторов и культурных детерминант.

Доказано, что институт образования участвует в воспроизводстве $и$ развитии сочииальной структуры общества, в осуществлении социальной мобильности и профессионального становления его членов, в структурной перестройке производства, в передаче культуры, иченностей, традиций и норм поведения.

Установлено, что использование возможностей нескольких методик (LOV и частично VALS) позволит раскрыть структуру изменения потребностей, интересов и иенностей, стилей жизни представителей различных соичиальных групп и сообществ, выявить их общественную природу и доминирующие тенденции транзитивного украинского общества. Проанализировано 
поведение потребителей услуг высшего образования, который позволил определить мотивачионную (потребности, интересы, иели, ожидания, установки, запросы) и иченностную (ценности, оценки, ожидания) структуру потребления.

Установлено, что помимо удовлетворения потребностей в познании $u$ понимании, потребление услуг в системе высшего образования может быть направлено на удовлетворение и других потребностей: в принадлежности и любви; в признании, в достижениях; в репутации, престиже и уважении других; в безопасности; в самоуважении и самореализации.

Ключевые слова: потребление, образовательные услуги, чуенности, потребности, образ жизни, поведение.

\section{Zoska Ya. V. Analysis of the concept and categorial apparatus of education consumption of educational services}

The article reveals that consumption is a complex set of activities that consists of consumption technology, consumer activity, and consumer behavior.

It has been proved that consumption occurs in the mind of the consumer, that is, a third party observer cannot evaluate the consumer through the stages of this process other than by external manifestations. Therefore, it can be argued that behavior is an external manifestation of the consumption process, and that is why a sociological analysis of consumer behavior in higher education allows us to describe not only the nature of the activity, but also its change under the influence of socio-economic factors and cultural determinants.

It is proved that the Institute of Education participates in the reproduction and development of the social structure of society, in the implementation of social mobility and professional formation of its members, in the structural restructuring of production, in the transfer of culture, values, traditions and norms of behavior.

It is established that the use of opportunities of several methods (LOV and partially VALS) will allow to reveal the structure of changing needs, interests and values, lifestyles of representatives of different social groups and communities, to reveal their social nature and dominant tendencies of transitive Ukrainian society. The behavior of consumers of higher education services is analyzed, which allowed to determine the motivational (needs, interests, goals, expectations, attitudes, requests) and value (values, assessments, expectations) structure of consumption.

It has been established that, in addition to meeting the need for cognition and understanding, the consumption of services in the higher education system can be directed to the satisfaction of several needs: belonging and love; in recognition of the following expressions: in achievement; in the reputation, prestige and respect of others; safe; in self-respect and self-actualization.

Key words: consumption, educational services, values, needs, lifestyle, behavior. 